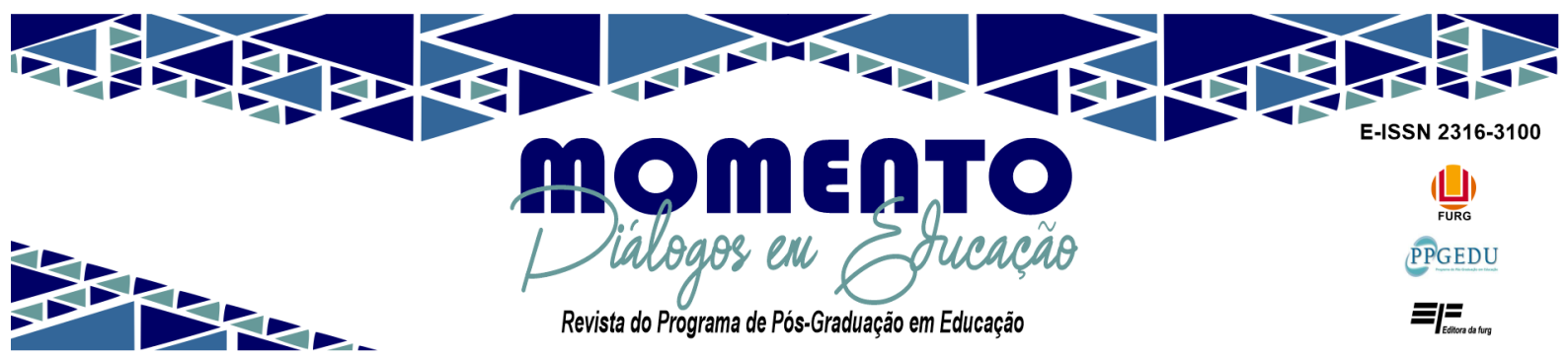

\title{
UMA ANÁLISE HISTÓRICO-CRÍTICA DA UNIDADE AFETIVO-COGNITIVA DA ARTE NA EDUCAÇÃO ESCOLAR
}

\author{
Mariana de Cássia Assumpção ${ }^{1}$ \\ Thiago Xavier de Abreu ${ }^{2}$
}

\begin{abstract}
Resumo: Este artigo versa sobre a unidade afetivo-cognitiva presente na arte como componente curricular da educação escolar. A heterogeneidade da vida cotidiana na sociedade capitalista acentua uma concepção dicotômica entre razão e emoção, atribuindo, no senso comum, os elementos racionais como pertencentes apenas à ciência e os elementos afetivos apenas à arte. Em oposição a tais perspectivas, entendemos a arte e a ciência como esferas superiores de objetivação que refletem, cada uma ao seu modo, a realidade objetiva e proporcionam uma síntese entre razão e emoção fundamental para o processo de formação dos indivíduos. Assim, nos baseamos nos escritos estéticos de György Lukács e na pedagogia histórico-crítica, em uma pesquisa de natureza teóricobibliográfica, observando a origem e o desenvolvimento dos reflexos artístico e científico a partir de uma análise dialética entre razão e emoção, tomando a música como uma modalidade artística que evidencia essa dialeticidade entre os aspectos racionais e emocionais. Por fim, defendemos uma formação omnilateral da individualidade, racional e afetivamente orientada para superação dos limites da vida cotidiana no capitalismo, acentuando a importância da transmissão dos conteúdos artísticos na educação escolar.
\end{abstract}

Palavras-chave: Unidade Afetivo-Cognitiva. Pedagogia Histórico-Crítica. György Lukács. Educação Escolar. Educação Musical.

\footnotetext{
${ }^{1}$ Graduada em Pedagogia, Mestre e Doutora em Educação Escolar pela Universidade Estadual Paulista, UNESP, campus de Araraquara. Trabalhou como professora na rede Estadual de São Paulo e na rede municipal de Araraquara. Atualmente é professora da Universidade Federal de Goiás, lotada no Centro de Ensino e Pesquisa Aplicados à Educação (CEPAE) Membro do grupo de Estudos Marxistas em Educação. Seus interesses de pesquisa concentram-se na área de fundamentos da educação com ênfase na psicologia históricocultural e a pedagogia histórico-crítica.

${ }^{2}$ Atua como músico desde 2001 e como educador musical desde 2004, tendo estudado, neste período, no Conservatório Musical Villa-Lobos, em São José dos Campos/SP. Em 2011 concluiu o curso de graduação Licenciatura em Artes - Música na UNICAMP (Universidade Estadual de Campinas). Em 2014, obteve o título de Mestre em Música pelo Instituto de Artes da UNESP (Universidade Estadual Paulista) com um estudo sobre as ideias pedagógicas de Murray Schafer, sob orientação de Marisa Fonterrada. Em 2018 torna-se Doutor em Educação Escolar pela Faculdade de Ciências e Letras da UNESP/Araraquara (FCLAr/UNESP), defendendo sua Tese sobre a educação musical escolar na perspectiva da pedagogia histórico-crítica, sendo orientado por Newton Duarte. Desde o início de sua trajetória profissional, Thiago vem atuando como professor em instituições de educação infantil, ensino fundamental e ensino superior, além de seguir com sua carreira artística como instrumentista, compositor e produtor em diversos conjuntos musicais, com destaque para a Skafandros Orkestra. Atualmente é professor no curso de Licenciatura em Música da UEPG (Universidade Estadual de Ponta Grossa/PR), onde leciona prioritariamente a disciplina de Estágio Supervisionado I. É integrante do grupo de pesquisa Estudos Marxistas em Educação, da FCLAr/UNESP, no qual desenvolve pesquisas no campo da Educação Musical Escolar, estudando as Teorias Pedagógicas com ênfase nos Processos de Ensino-Aprendizagem e na Filosofia da Educação.
} 


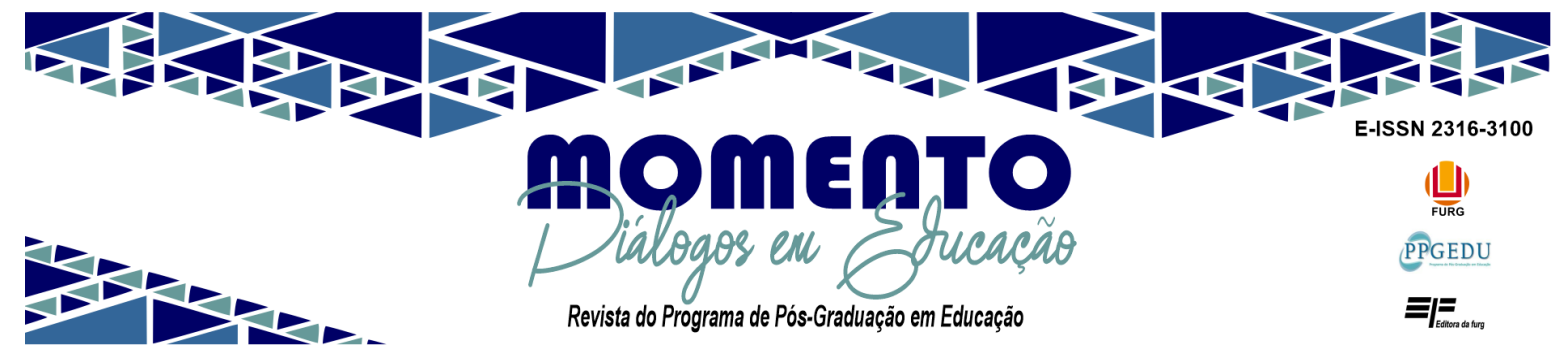

\title{
A HISTORICAL-CRITICAL ANALYSIS OF THE AFFECTIVE-COGNITIVE UNIT OF ART IN SCHOOL EDUCATION
}

\begin{abstract}
This article deals with the affective-cognitive unit present in art as a curricular component of school education. The heterogeneity of everyday life in capitalist society accentuates a dichotomous conception between reason and emotion, attributing, in common sense, the rational elements as belonging only to science and the affective elements only to art. In opposition to such perspectives, we understand art and science as higher spheres of objectification that reflect, each in its own way, the objective reality and provide a synthesis between reason and emotion that is fundamental to the formation process of individuals. Thus, we are based on the aesthetic writings of György Lukács and on historical-critical pedagogy, in a research of a theoretical-bibliographic nature, observing the origin and development of artistic and scientific reflexes from a dialectical analysis between reason and emotion, taking the music as an artistic modality that highlights this dialectic between rational and emotional aspects. Finally, we advocate an omnilateral formation of individuality, rationally and affectionately oriented towards overcoming the limits of everyday life in capitalism, emphasizing the importance of the transmission of artistic contents in school education.
\end{abstract}

Keywords: Affective-Cognitive Unit. Historical-Critical Pedagogy. György Lukács. Schooling. Musical Education.

\section{UN ANÁLISIS HISTÓRICO-CRÍTICO DE LA UNIDAD AFECTIVO-COGNITIVA DEL ARTE EN LA EDUCACIÓN ESCOLAR}

Resumen: Este artículo aborda la unidad afectivo-cognitiva presente en el arte como componente curricular de la educación escolar. La heterogeneidad de la vida cotidiana en la sociedad capitalista acentúa una concepción dicotómica entre razón y emoción, atribuyendo, en sentido común, los elementos racionales como pertenecientes únicamente a la ciencia y los elementos afectivos únicamente al arte. Frente a tales perspectivas, entendemos el arte y la ciencia como esferas superiores de objetivación que reflejan, cada una a su manera, la realidad objetiva y proporcionan una síntesis entre la razón y la emoción fundamental para el proceso de formación de los individuos. Así, nos basamos en los escritos estéticos de György Lukács y en la pedagogía histórico-crítica, en una investigación de carácter teórico-bibliográfico, observando el origen y desarrollo de los reflejos artísticos y científicos a partir de un análisis dialéctico entre la razón y la emoción, tomando la música como modalidad artística que resalta esta dialéctica entre lo racional y lo emocional. Finalmente, abogamos por una formación omnilateral de la individualidad, racional y afectivamente orientada a la superación de los límites de la vida cotidiana en el capitalismo, enfatizando la importancia de la transmisión de contenidos artísticos en la educación escolar.

Palabras clave: Unidad Afectivo-Cognitiva. Pedagogía Histórico-Crítica. György Lukács. Enseñanza. Educación Musical.

\section{Introdução}

$\mathrm{Na}$ atual conjuntura das ideias que permeiam a educação escolar certo senso comum pode ser verificado ao se questionar as especificidades da ciência e da arte para a formação 


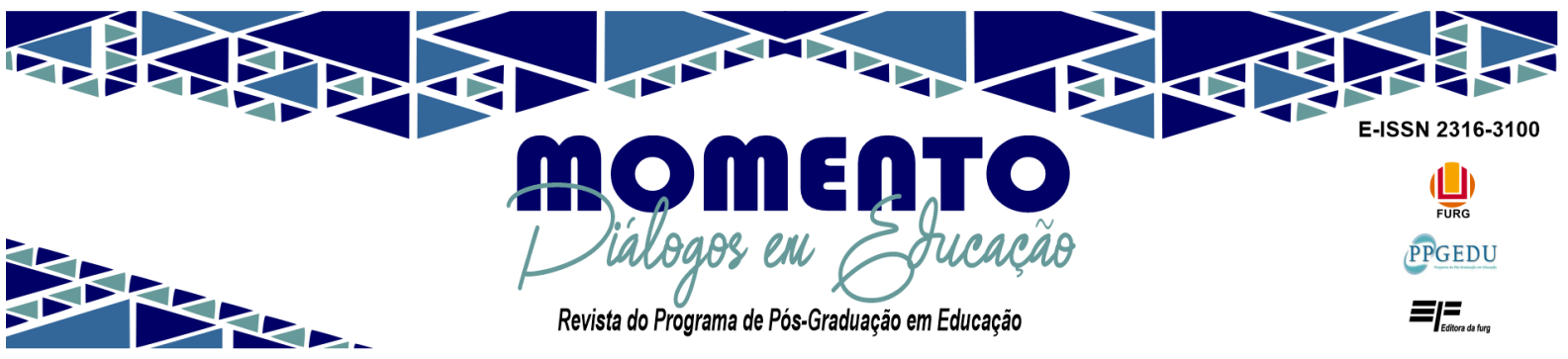

humana: a primeira estaria ligada aos processos de inteligibilidade da realidade, tendo prevalência dos aspectos cognitivos da atividade humana; a segunda, por sua vez, estaria relacionada prioritariamente ao enriquecimento da vida afetiva. De fato, o acento à racionalidade científica e à afetividade artística não são incoerentes com a natureza específica de cada uma dessas esferas de atividade humana e seus respectivos papéis na formação.

No entanto, observar os processos cognitivos como elementos exclusivos à atividade científica e, consequentemente, a arte como plena experiência afetiva, pode levar a uma visão dicotômica: não seria, a inteligibilidade científica do real, um processo carregado de emoções proporcionadas pelo conhecimento da realidade objetiva? Inversamente, a arte não seria também uma forma de conhecer o real, ao invés de pura mobilização e expressão de sentimentos $^{3}$ ? Não raro, esta visão dicotômica culmina no esvaziamento dos currículos escolares, reduzindo a ciência ao tecnicismo e a arte à experiência momentânea.

No âmbito da pedagogia histórico-crítica, o debate sobre a unidade afetivo-cognitiva não é propriamente uma novidade, sendo, antes, um pressuposto fundamental de uma formação omnilateral. Destacam-se, nesse sentido, os estudos provenientes da psicologia histórico-cultural (MARTINS, 2013; MARTINS, CARVALHO, 2016; MACHADO, FACCI, BARROCO, 2011; GOMES, 2014; LEITE, SILVA, TULESKI, 2013; MONTEIRO, ROSSLER, 2020).

Alinhados a tais contribuições, neste trabalho exploraremos a problemática por outro ângulo: defenderemos a unidade afetivo-cognitiva presente nos conteúdos escolares, como na arte e na ciência, analisando as origens e o desenvolvimento histórico dessa unidade, bem

\footnotetext{
${ }^{3}$ Martins (2004, p. 90-91) esclarece as diferenças entre emoções e sentimentos à luz da psicologia históricocultural. Nesse sentido, define emoção como: "Motiva reação emocional aquilo que acena positiva ou negativamente à satisfação dos motivos da pessoa. Expressam-se como reflexo sensorial direto ou vivência imediata da atualização do motivo em atividade, prescindindo, portanto, de mediações cognitivas". Já os sentimentos: "podem ter um caráter circunstancial ou constante e prolongado, podendo em sua manifestação, inclusive, independer de uma situação exatamente determinada. É por esta razão que os sentimentos dependem sempre de objetos e fenômenos em conjunto e não de suas propriedades isoladas, motivando-se por complexas relações temporais estabelecidas entre a experiência passada, as expectativas futuras e a realidade presente". No presente trabalho, apesar de abordarmos brevemente as diferenças entre emoções e sentimentos na discussão sobre o papel mediador do pensamento para o desenvolvimento da vida afetiva, não nos ateremos a tal diferenciação, tomando os conceitos "emoções" e "sentimentos" relativamente como sinônimos.
} 


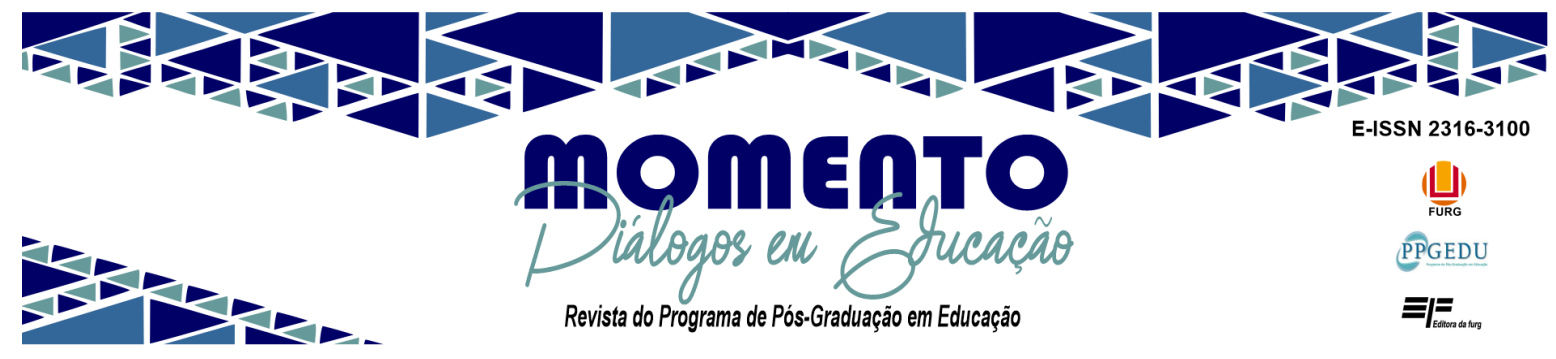

como das concepções que reservam a racionalidade à atividade científica e a afetividade à prática artística. A partir dessa análise derivaremos sua importância para a educação escolar, destacando a música como um conteúdo que expressa nitidamente a dialeticidade entre razão e emoção, apontando horizontes pedagógicos que proporcionem a apropriação da riqueza produzida genericamente e a consequente homogeneização da experiência do indivíduo.

\section{O desenvolvimento histórico da unidade afetivo-cognitiva na arte e na ciência}

Uma análise histórica da unidade afetivo-cognitiva requer que nos debrucemos sobre a atividade vital humana, produto da evolução dos processos orgânicos colocados em movimento e responsável pelas transformações objetivas e subjetivas empreendidas pelos indivíduos. Tal atividade é, pois, a atividade de trabalho, que é definida por Marx, em linhas gerais, como:

[...] um processo de que participam o homem e a natureza, processo em que o ser humano, com sua própria ação, impulsiona, regula e controla seu intercâmbio material com a natureza. Defronta-se com a natureza como uma de suas forças. Põe em movimento as forças naturais de seu corpo braços e pernas, cabeça e mãos -, a fim de apropriar-se dos recursos da natureza, imprimindo-lhes forma útil à vida humana. Atuando assim sobre a natureza externa e modificando-a, ao mesmo tempo em que modifica sua própria natureza. Desenvolve as potencialidades nela adormecidas e submete ao seu domínio o jogo das forças naturais. Não se trata aqui das formas instintivas, animais de trabalho, [...]. Pressupomos o trabalho sob forma exclusivamente humana [...]. No fim do processo do trabalho aparece um resultado que já existia antes idealmente na imaginação do trabalhador. Ele não transforma apenas o material sobre o qual opera; ele imprime ao material o projeto que tinha conscientemente em mira. (MARX, 2013, p. 211-212).

Foi por meio da atividade de trabalho que o ser humano construiu a realidade social e operou modificações decisivas em sua subjetividade, colocando sob outros moldes, os processos naturais, deixando-os cada vez mais mediatizados.

Os animais também agem sobre a natureza para sobreviverem. Mas a ação animal está determinada pela via genética e por seus traços adaptativos, os quais condicionam e impõem limites ao processo de interação. A relação do indivíduo, inicialmente, com a natureza, ao contrário da relação dos animais, pressupõe a ação consciente e a capacidade 


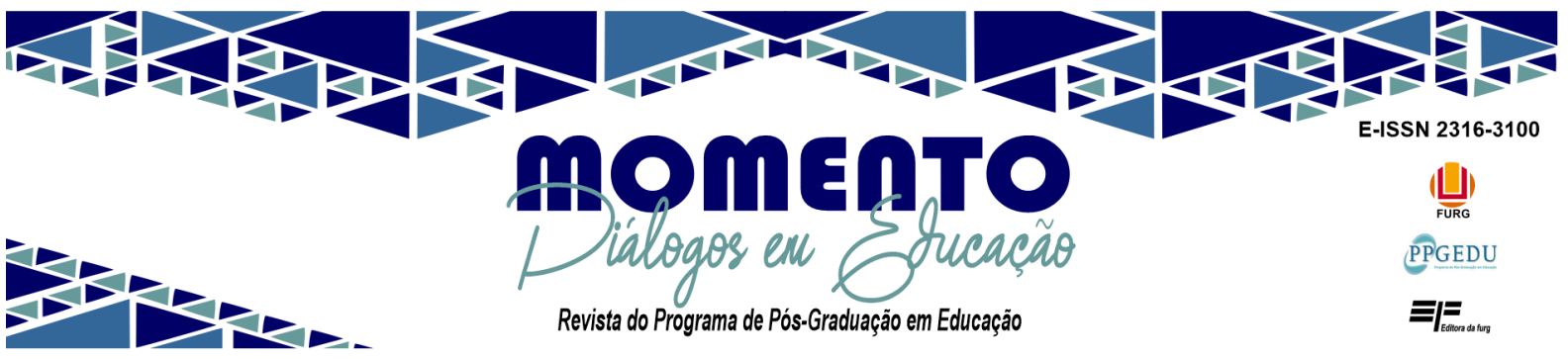

humana de estabelecer, mentalmente, o resultado final a que se destinam suas ações. Em entrevista, Lukács afirmou sobre esse assunto que "o homem é, antes de mais nada, como todo organismo, um ser que responde a seu ambiente. Isso significa que o homem constrói os problemas a serem resolvidos e lhes dá resposta com base na sua realidade" (KOFLER, ABENDROTH, HOLZ, 1969, p. 40). Em outras palavras, o trabalho, para o ser humano, é uma atividade racional e, sobretudo, teleológica que, além de apresentar o indivíduo como um ser ativo, ressalta a sua característica de planejar e de criar.

A relação entre o ser humano e a natureza transforma a ambos, ou seja, "humaniza" a natureza e "naturaliza" o ser humano, entendendo-se por "naturalização" do ser humano a incorporação, cada vez mais ampla, de elementos e processos da natureza à prática social. Ao mesmo tempo que o ser humano se torna cada vez mais social e, nesse sentido, cada vez menos, imediatamente natural, contraditoriamente (no sentido dialético do termo), o ser humano se torna cada vez mais, universalmente, natural, já que incorpora cada vez mais a natureza à prática social.

Disso concluímos que o indivíduo tem como base para sua existência as atividades que partem de elementos dados pela natureza e pela sociedade. A atividade teleológica e criadora caracterizou-se, em suas formas básicas, pela transformação da natureza pelos seres humanos, construindo-se uma realidade social e produzindo, objetiva e subjetivamente, transformações significativas nas forças, capacidades e habilidades humanas. O ser humano, diferentemente dos animais, faz da natureza objeto da sua consciência de modo a não se adaptar, totalmente, a ela, mas a modificá-la. Lukács (2009, p. 230), explicita que:

Com o trabalho, portanto, dá-se ao mesmo tempo, no plano ontológico, a possibilidade de desenvolvimento superior dos homens que trabalham. Já por esse motivo - mas, antes de mais nada, porque se altera a adaptação passiva, meramente reativa, do processo de reprodução ao mundo circundante, já que esse mundo circundante é transformado de maneira consciente e ativa -, o trabalho se torna não simplesmente um fato no qual se expressa a nova peculiaridade do ser social, mas, ao contrário, precisamente, no plano ontológico, também se converte no modelo de toda a nova forma de ser.

O salto qualitativo promovido pelo trabalho envolve também as transformações psíquicas que instituíram uma nova esfera do ser, propriamente social. O psiquismo, como 


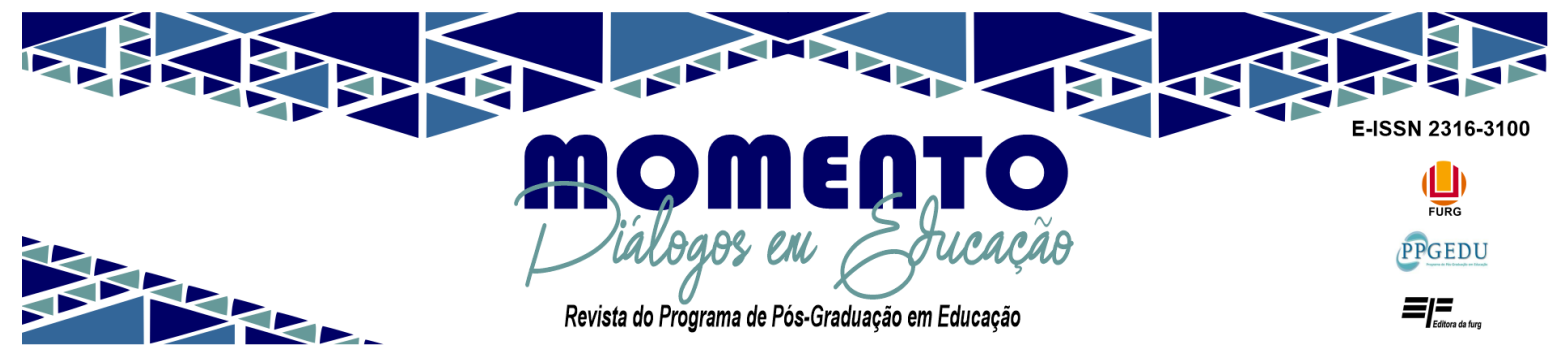

reflexo ideativo da ação prática do ser sobre a realidade, deixa de estar imediatamente ligado às determinações da natureza para ser mediado pela própria atividade humana, garantindolhe o caráter consciente. Nesse sentido, o desenvolvimento do psiquismo humano envolve sua especialização em um sistema psíquico com diferentes funções que elaboram uma imagem subjetiva da realidade objetiva em suas múltiplas determinações:

Em síntese, sensação, percepção, atenção, memória, linguagem, pensamento e imaginação colocam-se diretamente a serviço da formação da imagem do objeto à vista de sua concretude, isto é, da imagem fidedignamente representativa do real existente; visam, pois, ao reflexo da realidade objetiva. Tais processos funcionais representam as denominadas funções cognitivas, cujo parâmetro de qualidade se revela na inteligibilidade do real que promovem.

Ocorre, porém, que toda essa dinâmica de internalização abarca apenas parte do processo, uma vez que nenhuma imagem se institui na ausência de uma relação particular entre sujeito e objeto. Que o objeto afete o sujeito, esta se revela a primeira condição para sua instituição como imagem, a refletir também, além das propriedades objetivas do objeto, as singularidades da relação do sujeito com ele. Eis então a impossibilidade de qualquer relação entre sujeito e objeto isentar-se de componentes afetivos. (MARTINS, 2013, p. 243, grifos no original).

A formação da imagem subjetiva da realidade objetiva, do reflexo do real na consciência, envolve diversos processos funcionalmente distintos unidos em uma totalidade sistêmica que visam a inteligibilidade da realidade. Mas tais funções cognitivas seriam somente elementos ideativos, puramente abstratos, se não partíssemos do pressuposto de que elas se instituem em relações particulares entre o indivíduo realmente existente e a realidade objetiva. Isso significa que qualquer processo cognitivo não está separado da forma como um sujeito singular é afetado pelo objeto ou, em outras palavras, que o processo de inteligibilidade do real se dá como uma unidade afetivo-cognitiva. Se, por um lado, os processos cognitivos são motivados e sancionados pelos elementos afetivos que os permeiam, por outro, a própria vida afetiva humana se desenvolve a partir da mediação do pensamento:

O enfoque sistêmico que Vigotski defendera em relação a todos os processos funcionais reaparece, por certo, no tocante às emoções e aos sentimentos, em relação aos quais o autor também destacou o papel da internalização de signos e, especialmente, a formação de conceitos. Para 


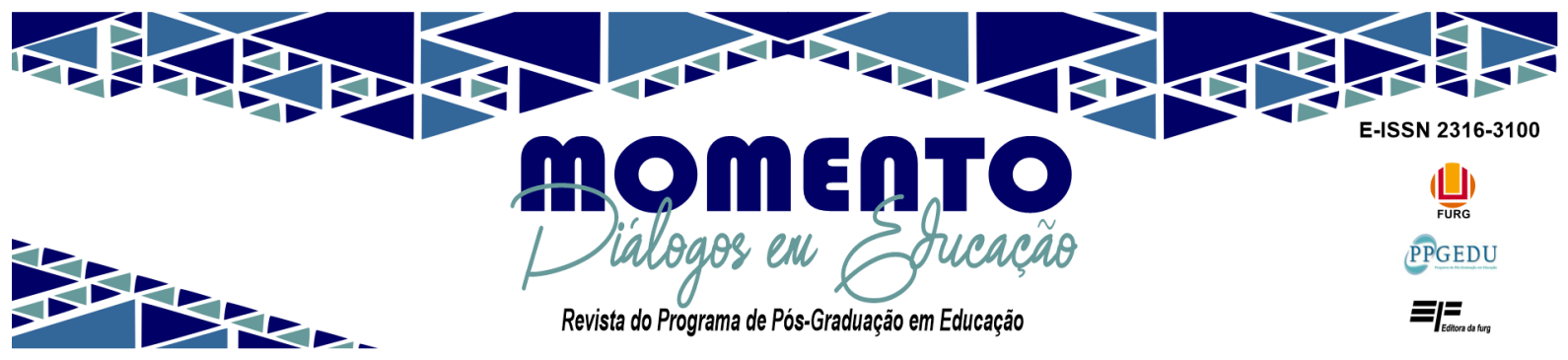

ele, o sistema de conceitos inclui os sentimentos e vice-versa, uma vez que o ser humano não sente simplesmente, mas percebe o sentimento na forma de seu conteúdo, ou seja, como medo, alegria, tristeza, ciúme, raiva etc. Portanto, os sentimentos são vividos como juízos, guardando sempre certa relação com o pensamento, na mesma medida em que o próprio pensamento não se isenta, em diferentes graus, dos sentimentos (MARTINS, 2013, p. 252).

Mas a unidade afetivo-cognitiva presente na atividade propriamente humana não pode obscurecer as especificidades das emoções e sentimentos no processo de trabalho. A centralidade da relação imediata de afecção do objeto perante o sujeito confere caraterísticas peculiares às impressões afetivas, como sua aparente irracionalidade - isto é, sua tendência a expressar-se de forma alheia à volição do indivíduo - e sua transitoriedade (MARTINS, 2013, p. 262).

Lukács (1967, p. 37) também aponta esses traços específicos das emoções e sentimentos frente aos outros elementos que constituem a interioridade humana destacando "a maior frouxidão de sua vinculação objetiva em comparação com outras formas de reação". Para o autor, "desde a simples percepção até o pensamento claro aparece uma intenção orientada a um determinado objeto (...) uma tendência em transformar o em-si desse objeto em um para-nós", ao passo que as emoções e sentimentos “determinam muito menos o para-nós objetivo da coisa que o comportamento puramente pessoal, puramente subjetivo do homem a respeito dela". Ou seja, as emoções e sentimentos são reflexos muito mais ligados ao comportamento do sujeito frente ao objeto do que às características do objeto e, assim, possuem uma vinculação com a realidade objetiva muito mais indireta do que outras funções psicológicas.

O desenvolvimento do psiquismo humano foi sendo aperfeiçoado cognitiva e afetivamente pela relação ativa do ser humano com a realidade na atividade de trabalho e na dinâmica de produção e satisfação de necessidades. Inicialmente, a produção de necessidades estava ligada aos aspectos de garantia da sobrevivência dos seres humanos. Entretanto, com o tempo, essas necessidades foram se desenvolvendo e se desligando do plano da sobrevivência. Segundo Lukács (2009, p. 233), isso aconteceu porque "enquanto o trabalho é realizado, a observação dos resultados etc. faz crescer continuamente a faixa de 


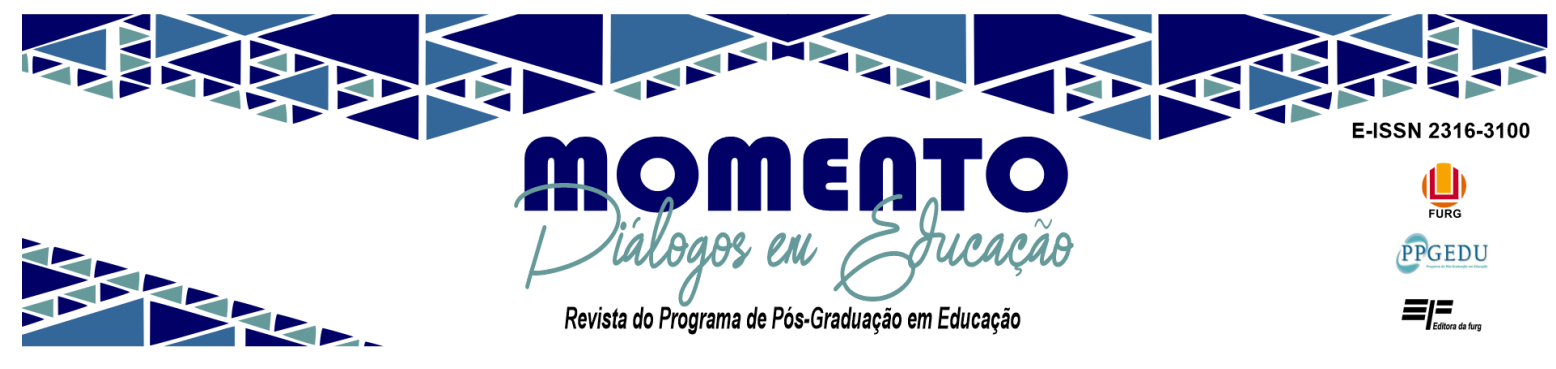

determinações que se tornam cognoscíveis e, por conseguinte, o trabalho se torna cada vez mais variado, abarca campos cada vez maiores".

Esse processo de produção e satisfação de necessidades cada vez mais complexas, demonstra o desenvolvimento dos indivíduos em um sentido mais enriquecido de determinações. Marx e Engels (2007, p. 43) afirmam que em cada nova geração:

Encontra-se um resultado material, uma soma de forças de produção, uma relação historicamente estabelecida com a natureza e que os indivíduos estabelecem uns com os outros; relação que cada geração recebe da geração passada, uma massa de forças produtivas, capitais e circunstâncias que, embora seja, por um lado, modificada pela nova geração, por outro lado prescreve a esta última suas próprias condições de vida.

A evolução constante das técnicas que otimizavam a atividade de trabalho significou um maior domínio da natureza pelo ser humano e, portanto, uma maior submissão da natureza às vontades dos indivíduos. O refinamento das habilidades humanas como, por exemplo, a capacidade de utilizar as mãos e, posteriormente, a precisão nos movimentos e na coordenação motora fina durante a execução da sua atividade inaugurou a possibilidade de humanizarmos os sentidos. Engels aponta como ocorreram essas morosas modificações nas formas de relação social por meio da atividade de trabalho:

Em face de cada novo progresso, o domínio sobre a natureza que tivera início com o desenvolvimento da mão, com o trabalho, ia ampliando os horizontes do homem, levando-o a descobrir constantemente nos objetos novas propriedades até então desconhecidas. Por outro lado, o desenvolvimento do trabalho, ao multiplicar os casos de ajuda mútua e de atividade conjunta, e ao mostrar assim as vantagens dessa atividade conjunta para cada indivíduo, tinha que contribuir forçosamente para agrupar ainda mais os membros da sociedade. (ENGELS, 2012, p. 22-23).

Pela interposição de mediações, de início, com instrumentos materiais, mas também em decorrência da universalização da linguagem, surgiram formas mais abstratas de expressão que se consolidaram nas esferas científica e artística. Tomando a música como exemplo, Marx (2010, p. 110) afirma que ela:

[...] desperta primeiramente o sentido musical do homem, assim como para o ouvido não musical a mais bela música não tem nenhum sentido, é 


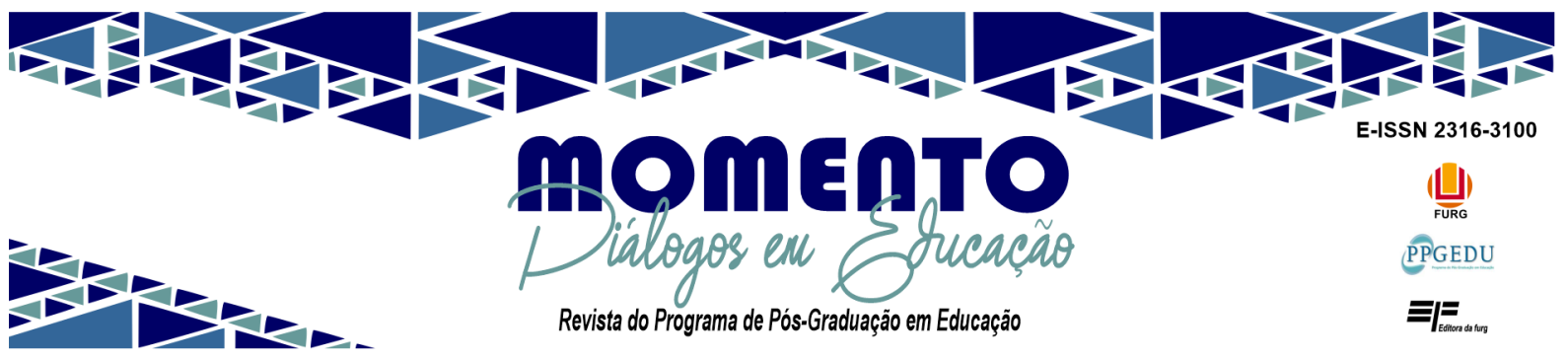

nenhum objeto, porque o meu objeto só pode ser a confirmação de uma das minhas forças essenciais, portanto só pode ser para mim da maneira como a minha força essencial é para si como capacidade subjetiva, porque o sentido de um objeto para mim (só tem sentido para um sentido que lhe corresponda) vai precisamente tão longe quanto vai o meu sentido, por causa disso é que os sentidos do homem social são sentidos outros que não os do não social; [é] apenas a riqueza objetivamente desdobrada da essência humana que a riqueza da sensibilidade humana subjetiva, que um ouvido musical, um olho para a beleza da forma, em suma as fruições humanas todas se tornam sentidos capazes, sentidos que se confirmam como forças essenciais humanas, em parte recém-cultivados, em parte recém-engendrado.

Esse processo de progressiva complexidade das objetivações faz consolidar "um mundo social, humano, enfim, em que a espécie humana se converte inteiramente em gênero humano" (PAULO NETTO, BRAZ, 2012, p. 56, grifos no original). O exemplo da humanização dos órgãos dos sentidos é bastante ilustrativo para evidenciar a relevância da atividade de trabalho para a formação da individualidade. Assim, a arte se constituiu como um produto da ação humana mais elaborada, justamente por requisitar dos indivíduos capacidades cognitivas e afetivas mais desenvolvidas, que extrapolaram os limites da subsistência e inauguraram as tentativas de compreender a si mesmo, bem como entender o mundo e os seus fenômenos.

A arte, assim como a ciência, é uma das esferas da produção não material, cujas relações com as necessidades humanas não se caracterizam por uma linearidade do tipo necessidade $\rightarrow$ produção do objeto que satisfaz essa necessidade. O objeto artístico é, igualmente, um produtor de necessidades que pode levar o indivíduo para além das fronteiras restritas da vida cotidiana.

Uma vez que o desenvolvimento do ser social demandava o aperfeiçoamento das ações cognitivas e afetivas sobre a realidade, esferas superiores de objetivação foram sendo progressivamente estabelecidas, como vimos, como reflexos cada vez mais elaborados da realidade objetiva. Algumas formas de reflexo eram desantropomorfizadoras, isto é, visavam transformar "em algo para nós, com a máxima aproximação possível, o que é em si na realidade, na sua objetividade, na sua essência, suas leis" (LUKÁCS, 1968, p. 296), constituindo o que veio a ser chamado, na modernidade, de ciência. Inversamente, outras formas de reflexo eram antropomorfizadoras, criando novas reproduções da realidade para 


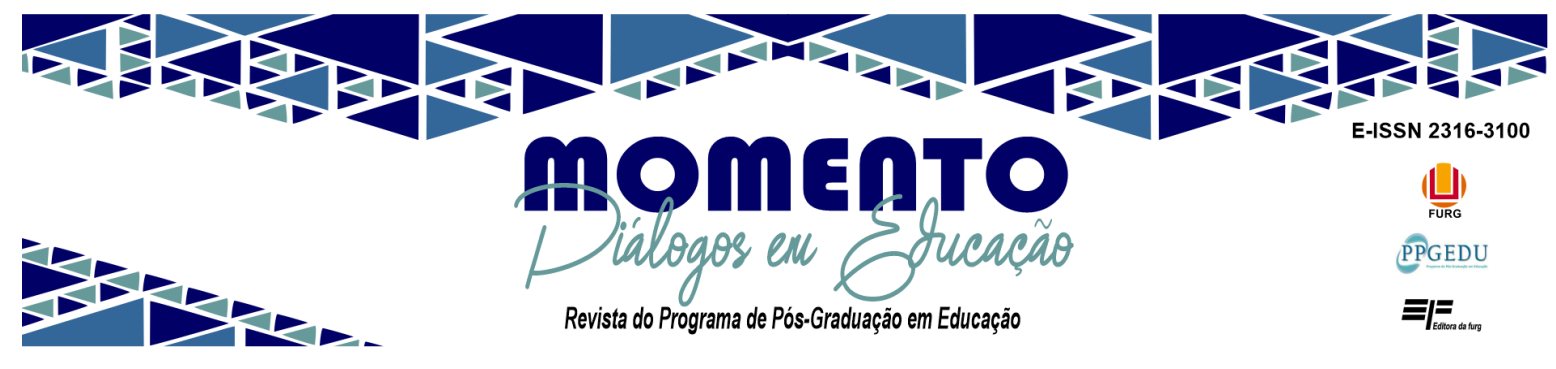

refletir o próprio ser humano, proporcionando "um para-si do sujeito, uma autoconsciência" (LUKÁCS, 1968, p. 296); trata-se da arte. Ambas formas de reflexo envolviam processos cognitivos e afetivos, mas os traços específicos das emoções e sentimentos na vida humana impuseram também especificidades quanto ao processo de reflexão:

Acrescentemos novamente, para evitar qualquer mal-entendido, que essa impotência em que se encontra a vida, sua incapacidade de fazer com que os sentimentos como tais tenham um desenvolvimento experiencial total, não é, considerada com essa generalidade, nenhuma limitação, nem no sentido social e nem em um sentido universalmente humano, mas uma consequência necessária das únicas reações práticas possíveis do homem ao mundo ao seu redor. $\mathrm{O}$ fato de que - como complemento a esta situação - realmente exista a necessidade da plena realização dos sentimentos, o fato de sua realização mimética enriquecer e aprofundar o homem, mostra sem dúvida também que a maioria das formações sociais coloca obstáculos no caminho do desenvolvimento omnilateral do homem, mas, sobretudo, que este desenvolvimento omnilateral das capacidades humanas exige um instrumento produzido pelo próprio homem e que complemente, amplie e aprofunde a sua existência natural. (LUKÁCS, 1967, p. 41).

A vida cotidiana, na qual se desdobra a história da prática humana, impõe limites para o pleno desenvolvimento das emoções e sentimentos. Tais limites são, em parte, decorrentes de suas das características como funções psíquicas, de sua "frouxidão" perante a realidade objetiva; por outro lado, a própria necessidade humana de buscar um pleno desenvolvimento de sua vida afetiva, ao mesmo tempo, demonstra os limites da cotidianidade e a necessidade da criação de instrumentos para garantir esse desenvolvimento.

Lukács analisa, por exemplo, o salto qualitativo do ritmo como organização do processo de trabalho ao seu domínio estético pela música, proporcionando um desenvolvimento da vida interior humana. Para o autor, "a diminuição do esforço com o aumento do efeito do trabalho traz consigo o início de uma liberação da interioridade, da expansão das sensações que acompanham o trabalho" (LUKÁCS, 1967, p. 17, grifos nossos). Por meio do reflexo mimético tais impressões são fixadas em formas objetivas (o ritmo musical), cuja finalidade está muito mais ligada a uma relação consciente com a vida interior do próprio ser humano do que ao atendimento utilitário das necessidades imediatas. Porém, a autonomia da música como uma atividade conscientemente voltada para esse 


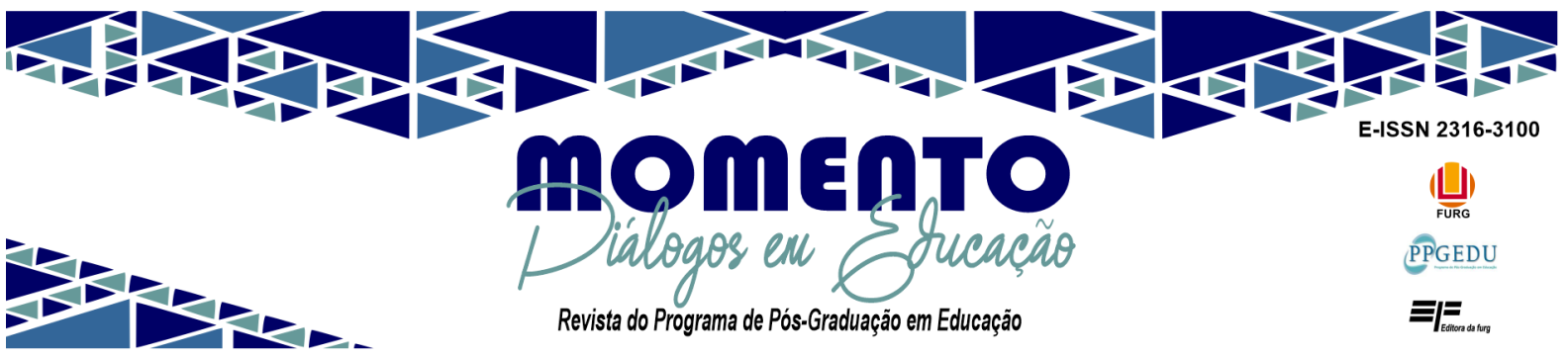

desenvolvimento da vida interior humana não se deu logo no ponto de partida da prática social; para Lukács, as manifestações artísticas "nasceram como uma consequência necessária da contemplação mágica da realidade, como consequência do esforço mágico para influenciar as forças e poderes ocultos que dominar a vida humana", sendo, antes, "meios técnicos auxiliares, por assim dizer, de um propósito mágico" (LUKÁCS, 1967, p. 18). Como nos explica Kiralyfálvi:

Lukács acredita que nas sociedades primitivas não existia separação nos modos de reflexo. O que mais tarde se separa em reflexos científico, religioso e artístico, distintamente diferentes um do outro, são, nesta fase de desenvolvimento, indistinguíveis. O ritual primitivo contém elementos científicos (utilitários), religiosos (mágicos) ${ }^{4}$ e artísticos (formais). $\mathrm{O}$ criador é cientista, sacerdote (mago) e artista, todos ao mesmo tempo, fazendo o que ele faz para o bem-estar da comunidade, para a sobrevivência. A partir daí, o primeiro estágio de desenvolvimento da arte consiste na separação da reflexão antropomórfica (arte e religião), da reflexão (científica) desantropomórfica. O segundo estágio é uma divisão dentro da categoria de reflexão antropomórfica, isto é, a separação da arte da religião. (KIRALYFALVI, 1983, p. 124).

Um ritual ancestral de cura abarcava tanto o domínio do princípio ativo de uma planta (desantropomorfização), quanto expressões miméticas por meio do som, imagens e movimento (música, dança, interpretação teatral etc.; em suma, reflexos antropomórficos) que enriqueciam subjetivamente o mero ato de tomar um chá. Mas, tal diferenciação somente é perceptível aos nossos olhos hodiernos, já que essas atividades também eram unificadas na consciência do indivíduo que as praticava. Elas envolviam tanto funções cognitivas quanto afetivas, pois a extração de um princípio ativo não estava separada da sensação afetiva proveniente do domínio da realidade objetiva, bem como a organização expressiva dessas sensações em meios artísticos depende da inteligibilidade sobre a própria subjetividade humana. Nas palavras de Fischer, “a mágica do fazer instrumentos levou-o [o

\footnotetext{
${ }^{4}$ Apesar de que neste excerto Kiralyfálvi trate a magia e a religião de forma semelhante, Lukács faz uma relativa distinção entre estas duas atividades. Para Lukács, a magia está mais diretamente ligada ao esforço por dominar a natureza. Ela surge antes da religião, mas não desaparece com o surgimento da religião, que incorpora a magia em seus rituais. Sobre essa diferença, veja Lukács (1966, pp. 104-105).
} 


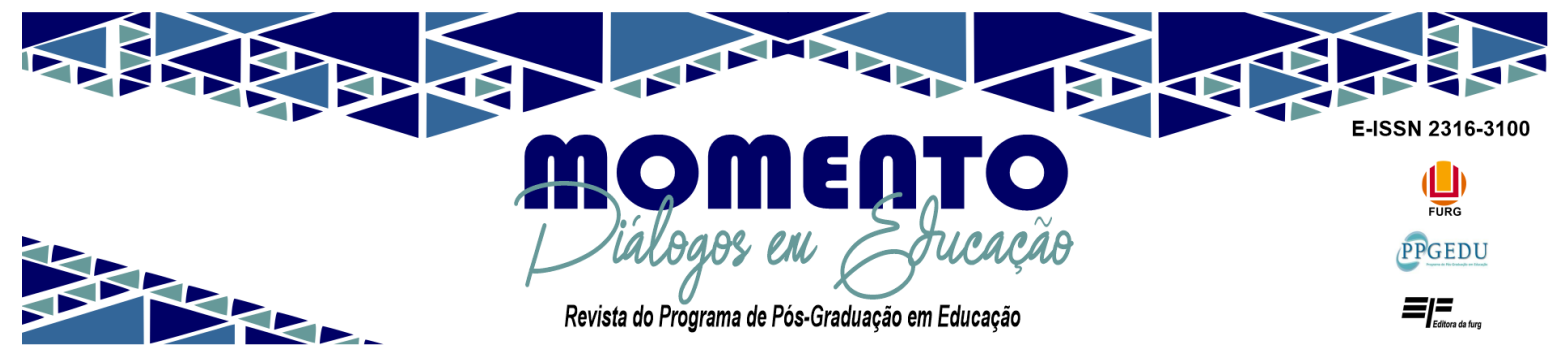

ser humano] inevitavelmente à tentativa de estender a magia ao infinito" (FISCHER, 1959, p. 43, intervenção nossa entre colchetes).

\begin{abstract}
A função decisiva da arte nos seus primórdios foi, inequivocamente, a de conferir poder: sobre a natureza, sobre os inimigos, sobre o parceiro das relações sexuais, sobre a realidade, poder exercido no sentido de um fortalecimento da coletividade humana. Nos alvores da humanidade, a arte pouco tinha a ver com a "beleza" e nada com a contemplação estética: era um instrumento mágico, uma arma da coletividade humana em sua luta pela sobrevivência (...).

No entanto, criando a arte, [o ser humano] encontrou para si um modo real de aumentar o seu poder e de enriquecer a sua vida. As agitadas danças tribais que precediam uma caçada realmente aumentavam o sentimento de poder da tribo; a pintura guerreira e os gritos de guerra realmente tornavam o combatente mais resoluto e mais apto para atemorizar o inimigo. As pinturas de animais nas cavernas realmente ajudavam a dar ao caçador uma sensação de segurança e superioridade sobre a presa. As cerimônias religiosas, com suas convenções estritas, realmente ajudavam a instilar a experiência social de cada membro da tribo e a tornar cada indivíduo parte do corpo coletivo. O homem, aquela fraca criatura que se defrontava com uma natureza perigosa e incompreensivelmente aterradora, era muitíssimo ajudado em seu desenvolvimento pela magia. (FISCHER, 1959, p. 45-46, intervenção nossa entre colchetes).
\end{abstract}

Mas a prática da magia como componente central da organização social só poderia ocorrer em estágios ainda pouco desenvolvidos das forças produtivas humanas, nos quais era necessária "uma forma densa e fechada de coletivismo", onde "o coletivo significava a vida e o conteúdo da vida" (FISCHER, 1959, p. 47).

Com surgimento da divisão social do trabalho, da propriedade privada e da formação das sociedades de classes, os reflexos desantropomórficos e antropomórficos vão progressivamente se emancipando e adquirindo novas funções sociais. Para Jaeger, por exemplo, o início da filosofia científica não coincide "nem com o princípio do pensamento racional nem com o fim do pensamento mítico"; de acordo com o autor, "devemos encarar a história da filosofia grega como o processo de racionalização progressiva da concepção religiosa do mundo implícita nos mitos" (JAEGER, 2013, p. 192). Já do prisma dos seus desdobramentos técnicos, a desantropomorfização caminha no sentido da plena aplicabilidade e eficiência do trabalho, da "nítida separação que se cria entre a técnica em sentido científico e prático-industrial (estreitamente ligados entre si) e a técnica em sentido 


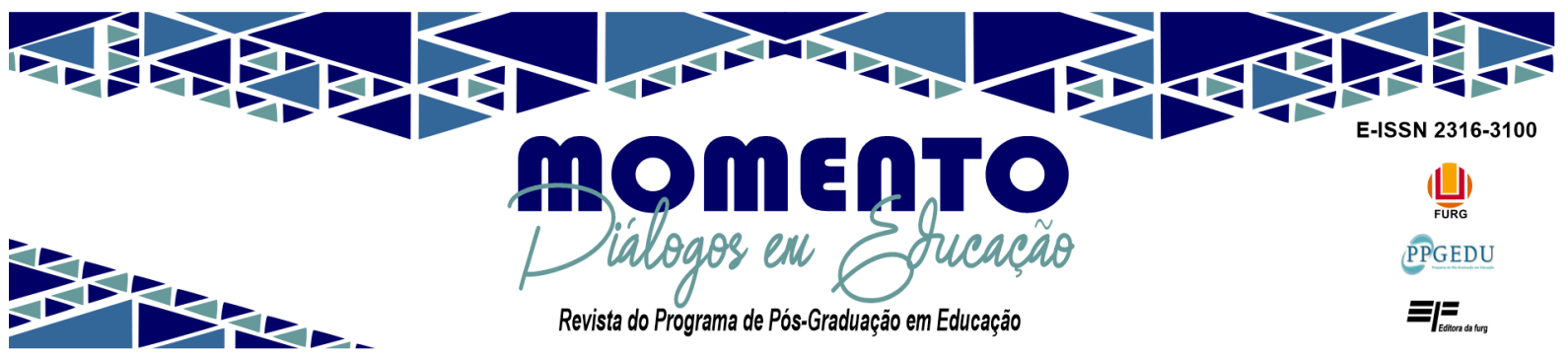

artístico", sendo que nas primeiras "o essencial é o fato de ser ela destacada da subjetividade humana. Não do ponto de vista da finalidade, naturalmente" (LUKÁCS, 1968, p. 187).

Esse amadurecimento e crescente autonomia dos reflexos desantropomórficos proporcionou a elevação de sua capacidade em tornar do em-si da realidade um para-nós, aumentando progressivamente as forças produtivas, confirmando a natureza universal e livre da atividade humana (MÁRKUS, 2015; DUARTE, 2013). Em contrapartida, a contraditoriedade do desenvolvimento do trabalho - seu duplo caráter, simultaneamente humanizador e alienador - fez com que tal emancipação da racionalidade ganhasse também a forma de contraposição à afetividade, como aponta Vigotski acerca do pensamento cartesiano (MARTINS, 2013; MARTINS, CARVALHO, 2016; MACHADO, FACCI, BARROCO, 2011; GOMES, 2014), ao passo que a superação dos resíduos subjetivos na técnica produtiva levou a cenários como a subsunção real do trabalhador à maquinaria industrial (MARX, 2013).

Do ponto de vista da arte, o desenvolvimento histórico não se apresenta menos contraditório. Se a função da arte na prática da magia era afirmar o "sentimento de identidade de tudo o que existia - identidade implícita no clã -, a arte [nas sociedades de classes] se torna uma expressão dos primórdios da alienação" (FISCHER, 1959, p. 48, intervenção nossa entre colchetes). A diferenciação da unidade presente no comunismo primitivo em estratos sociais impôs a autonomia da arte como recurso da manutenção dessa unidade, da experiência coletiva já não mais existente como totalidade prática; o reflexo da sociedade alienada é elevado à condição de momento humanizador, promovendo o que Lukács chama de autoconsciência do desenvolvimento da humanidade (LUKÁCS, 1968).

$\mathrm{Na}$ modernidade, essa relação contraditória se intensifica. A cisão entre o indivíduo e a coletividade chega ao seu máximo grau no capitalismo, quando a amplificação das relações de troca contrapõe o trabalho concreto individual à primeira forma universal de sociedade, o abstrato mercado (MARX, 2013). Trata-se da passagem do que Duarte (2013) chamou de uma individualidade concreta particular a uma individualidade abstrata universal.

Como nos explica Fischer (1959, p. 55-56), na arte "a experiência individual tornarase tão importante que já podia ter expressão própria, ao lado da crônica tribal, da épica heroica, dos cantos sagrados e das canções de guerra", mas isso não significava um mergulho 


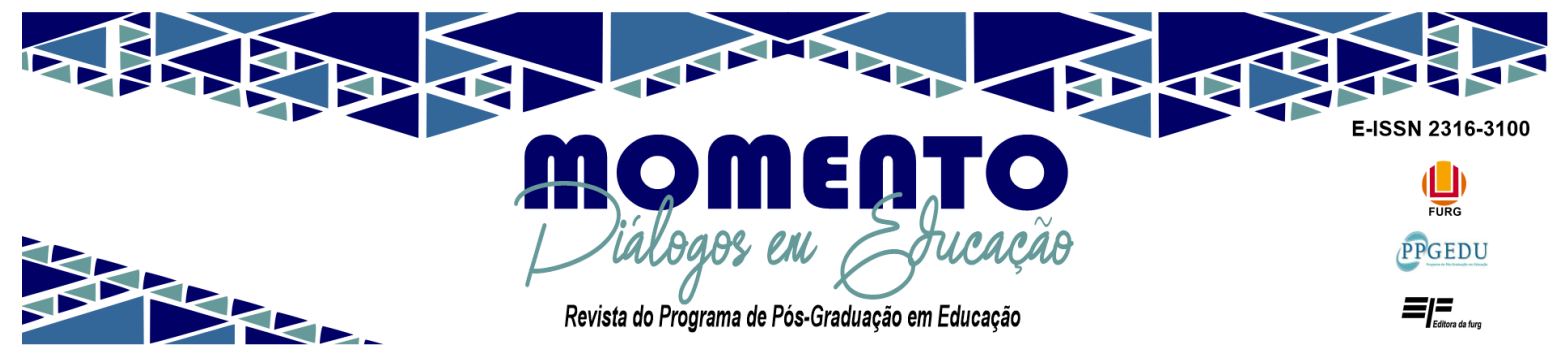

isolado na experiência individual, já que "o elemento social ou coletivo se tinha subjetivizado no 'eu', mas o conteúdo essencial da personalidade continuava e continua ainda hoje a ser social". Daí que o senso comum e algumas teorias estéticas imponham também certa cisão entre a afetividade e a racionalidade na prática artística, inversamente à ciência, supervalorizando a primeira; uma separação artificial, já que:

Para conseguir ser um artista, é necessário dominar, controlar e transformar a experiência em memória, a memória em expressão, a matéria em forma. A emoção para um artista não é tudo; ele precisa também saber tratá-la, transmiti-la, precisa conhecer todas as regras, técnicas, recursos, formas e convenções com que a natureza - esta provocadora - pode ser dominada e sujeitada à concentração da arte. A paixão que consome o diletante serve ao verdadeiro artista; o artista não é possuído pela besta-fera, mas doma-a. (FISCHER, 1959, p. 14).

Tendo em vista a análise do desenvolvimento histórico da unidade afetivo-cognitiva aqui apresentada, evidencia-se com clareza a artificialidade das perspectivas que observam de maneira dicotômica a razão e a emoção nas artes e na ciência; antes, tais concepções parecem corresponder às funções que cada uma dessas esferas de objetivação ocupam na sociedade capitalista, reduzindo a ciência ao pragmatismo e à neutralidade técnica e a arte ao subjetivismo da experiência e da expressão afetiva individual. Tal problemática estendese aos processos de transmissão dos saberes científicos e artísticos, promovendo formas específicas de esvaziamento dos conteúdos escolares. Inversamente, a defesa de uma compreensão dialética da unidade afetivo-cognitiva aponta para a formação de um indivíduo omnilateral, homogêneo, com o horizonte de uma formação humana mais livre e universal.

\section{A unidade afetivo-cognitiva e educação escolar}

A separação artificial entre razão e emoção, difundida de várias maneiras no pensamento moderno, projeta-se também em concepções dicotômicas acerca dos conteúdos escolares, constituindo um dos determinantes dos esvaziamentos dos currículos. Um dos possíveis desdobramentos dessa problemática permeia as perspectivas educacionais que adjetivam a escola como "conteudista", e implicitamente sustentam uma visão tecnicista dos conteúdos escolares ao reduzi-los à condição de instrumentos técnicos de inteligibilidade do 


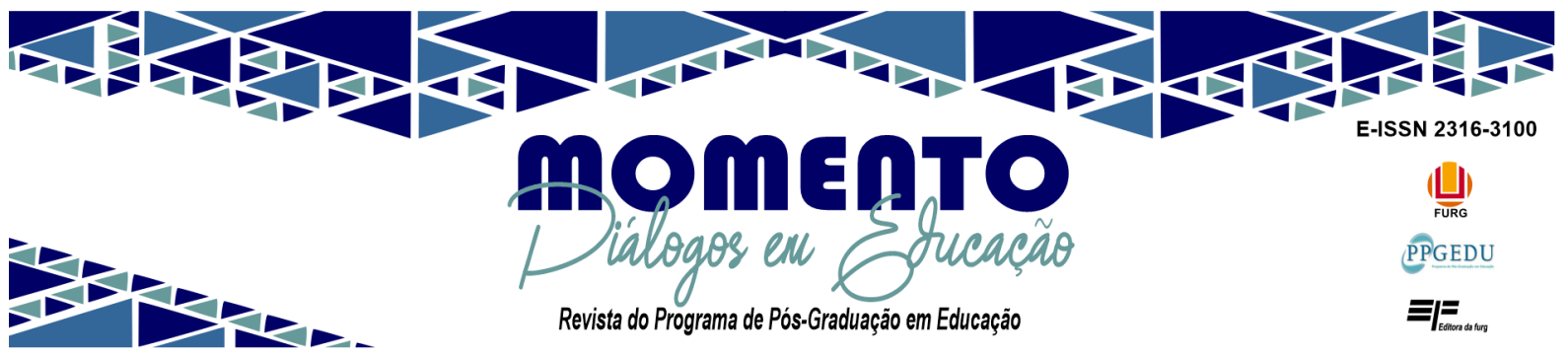

real. Essas teorias pedagógicas não percebem, contudo, que os conteúdos escolares estão inseridos nos embates ideológicos que acompanham a luta de classes, e que ensinar determinado conteúdo é também educar afetivamente o aluno frente a esta luta, na medida em que se trata da formação de uma concepção de mundo. Como nos explica Duarte:

Ensinar conteúdos escolares como ciências, história, geografia, artes, educação física, língua portuguesa e matemática é ensinar as concepções de mundo veiculadas por esses conhecimentos, ou seja, é educar. Por menos explícitas que sejam as concepções de mundo presentes nos conhecimentos ensinados na escola, elas sempre existem, o que faz do ensino desses conhecimentos sempre um ato educativo, o que desautoriza a afirmação de que ensinar não é educar. Quando a pedagogia históricocrítica é adjetivada, por seus opositores, como "conteudista", trata-se da acusação de que a preocupação com o ensino dos conteúdos escolares descuidaria do sentido que esses conteúdos teriam ou não para a vida real dos alunos. A adjetivação pejorativa resumida na palavra "conteudista" assume o pressuposto de que os conhecimentos podem ser acumulados na mente de um indivíduo sem que isso gere impactos significativos sobre sua prática social. Ocorre que esse pressuposto não resiste a uma análise que, em vez de pautar-se no estabelecimento de relações imediatas e pragmáticas entre pensamento e ação, compreenda as relações, constituídas histórica e dialeticamente, entre conhecimentos, concepções de mundo e prática social. (DUARTE, 2016, p. 95-96).

No caso da arte o acento se desloca da visão tecnicista e pragmática dos conteúdos escolares para o subjetivismo da experiência afetiva, configurando uma forma específica de esvaziamento dos currículos. Essa tendência se fundamenta nas especificidades da arte como unidade afetivo-cognitiva: uma vez que sua função social está muito mais ligada à capacidade de sentir um "momento da humanidade" - para utilizar as palavras de Fischer (1959, p. 17) -, a dimensão afetiva do reflexo é decisiva. Isso porque, na arte, "a essência se dissolve completamente no fenômeno" (LUKÁCS, 1968, p. 221) e, assim, o processo de elaboração das formas de se tornar a essência da realidade objetiva algo a ser sentido, algo que afete, é fundamental. Para Lukács, esse "caráter inseparavelmente espiritual-sensível [...] é ainda mais claramente perceptível quando na forma parece ser mais incontestável o caráter sentimental" (LUKÁCS, 1968, p. 279), isto é, em reflexos nos quais a mobilização de emoções e sentimentos é um dos princípios centrais de organização, como na música. 


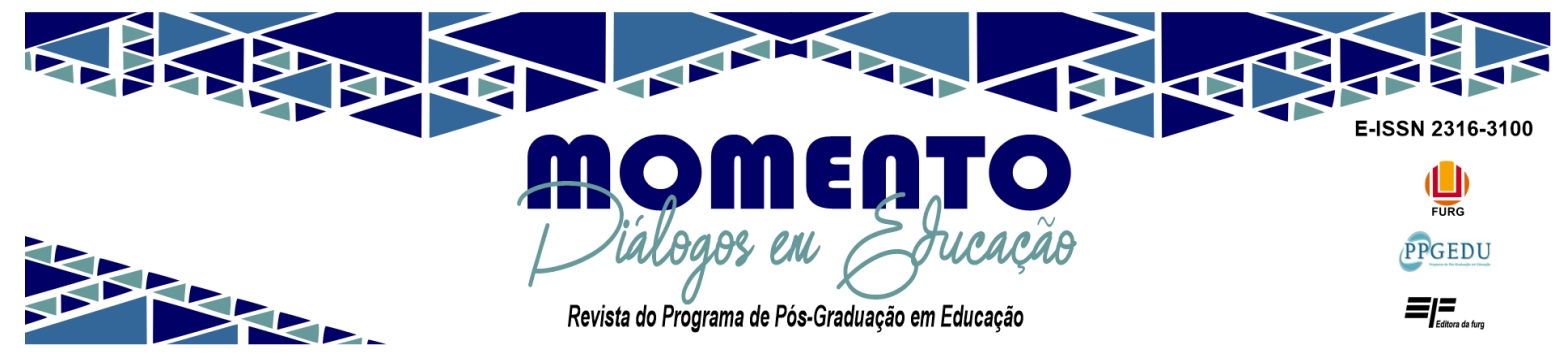

O que precede basta para descrever os contornos do meio homogêneo da música de um modo grosseiramente geral. As demais artes refletem imediatamente a concreta objetividade do mundo externo e do mundo interno humanos, e as concretas formas de objetividade assim conseguidas - e relevantes desde o ponto de vista que estamos tratando da arte - se homogeinizam em composições unitárias nas quais se expressa o funcionamento orientador, suscitador de evocações, das formas esteticamente criadoras. Em contrapartida, o meio homogêneo da música se limita estritamente a esse papel orientador, evocador. (LUKÁCS, 1967, p. 47).

A ênfase na mobilização das emoções e sentimentos não é uma exclusividade da música; na forma literária lírica, por exemplo, o destaque à afetividade é central. Contudo, por mais que a lírica se diferencie de outros gêneros literários por sua acentuação afetiva, ela também se caracteriza por refletir "imediatamente a concreta objetividade do mundo externo": o conteúdo lírico na literatura é formulado, por exemplo, narrando a história de um amor impossível entre dois jovens. Diferentemente, a música "pode expressar os sentimentos e as emoções dos homens com uma plenitude sem inibições, com uma pureza sem perturbações, precisamente porque libera a mimese da realidade [...] de toda sua ambígua vinculação aos objetos" (LUKÁCS, 1967, p. 44). Ou seja, a música, como reflexo antropomórfico, está voltada mais diretamente à vida interior do ser humano do que à sua vida exterior, como se todo seu meio homogêneo, sua organização espiritual-sensível, girasse exclusivamente em torno da mobilização imediata de emoções, e isso ocorre justamente porque seus elementos estéticos (melodia, harmonia etc.) não são coisas ou fatos observáveis, mas sim formas de expressão da interioridade em si mesma, em sua pureza afetiva.

Essa peculiaridade da afecção imediata das emoções presente em todas as modalidades artísticas, mas destacadamente central no caso da música, foi um dos determinantes para a valorização da experiência estética presente nas ideias educacionais sobre a música. Como nos mostra Fonterrada (2008, p. 177), "das propostas dos cinco educadores musicais mais influentes do início do século XX”, o ponto em comum mais importante é que "todas elas descartam a aproximação da criança com a música como procedimento técnico ou teórico, preferindo que entre em contato com ela como experiência de vida". 


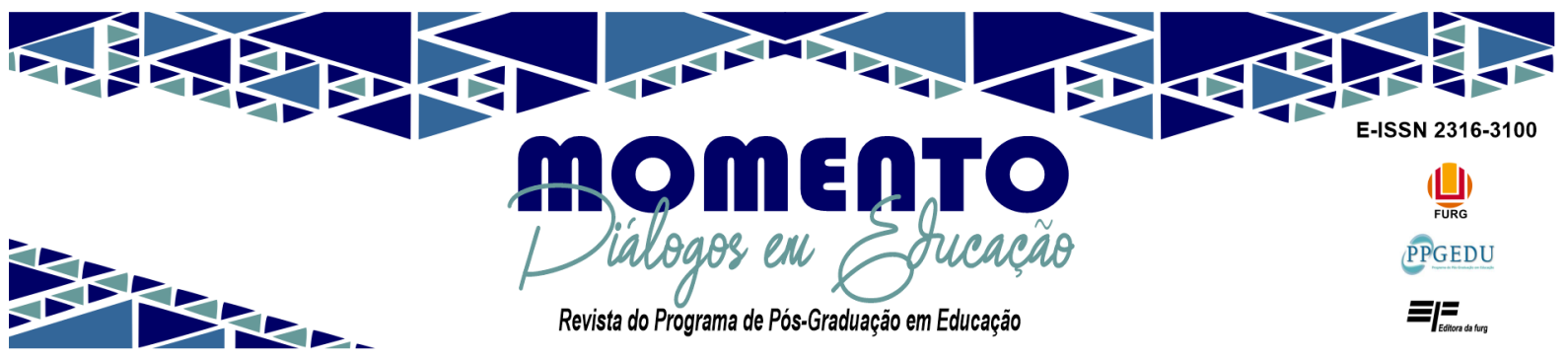

É certo que essa ênfase na experiência não é uma exclusividade da educação musical do século XX, sendo, antes, um elemento presente em todo pensamento educacional hegemônico deste período, que em grande parte se fundamenta nas bases filosóficas do pragmatismo. Como nos mostra Anísio Teixeira, John Dewey, um dos principais nomes dessa corrente filosófica, define a educação como "o processo de reconstrução e reorganização da experiência, pelo qual the percebemos mais agudamente o sentido, e com isso nos habilitamos a melhor dirigir o curso de nossas experiências futuras" (TEIXEIRA, 2010, p. 37). Mas as especificidades da música como reflexo antropomórfico da realidade, sua ênfase na afetividade, fazem com que a experiência estética ganhe centralidade nos processos educacionais. Para John Paynter, renomado teórico da educação musical, por exemplo,

Música não tem passado; ela só existe no momento em que acontece, e não há duas performances idênticas. Isto não é uma desvantagem. Pelo contrário, é o maior patrimônio da música, porque, talvez mais do que qualquer outra coisa em nossa experiência, ela evoca o essencial "agora", sem implicações de um passado e um futuro potencial (PAYNTER, 2002, p. 216).

Com a supervalorização da experiência estética as perspectivas educacionais da música passam a dar cada vez mais valor à composição musical como processo educativo. Escutar uma música ou realizar uma interpretação seriam experiências musicais válidas, mas não conteriam o mesmo potencial educativo da composição. Mais ainda: deve-se partir da própria composição do aluno, do que ele está fornecendo como um produto composicional, para depois questionar-se o porquê deste aluno ter realizado as escolhas que determinaram a este conjunto de sons a denominação de "música". De acordo com Paynter, (PAYNTER, 2000, p.7) "o caminho mais seguro para ajudar os alunos a compor melhor é incentivá-los a pensar sobre a essência do processo musical, não como regras abstratas, mas diretamente em relação ao que eles mesmos criam". O professor, por sua vez, não deve pretender ensinar qualquer conteúdo escolar da música, mas sim aflorar a criatividade intrínseca ao aluno. Nas palavras de Murray Schafer (SCHAFER, 1991, p. 282), "a melhor coisa que qualquer professor pode fazer é colocar na cabeça dos alunos a centelha de um tema que faça crescer 


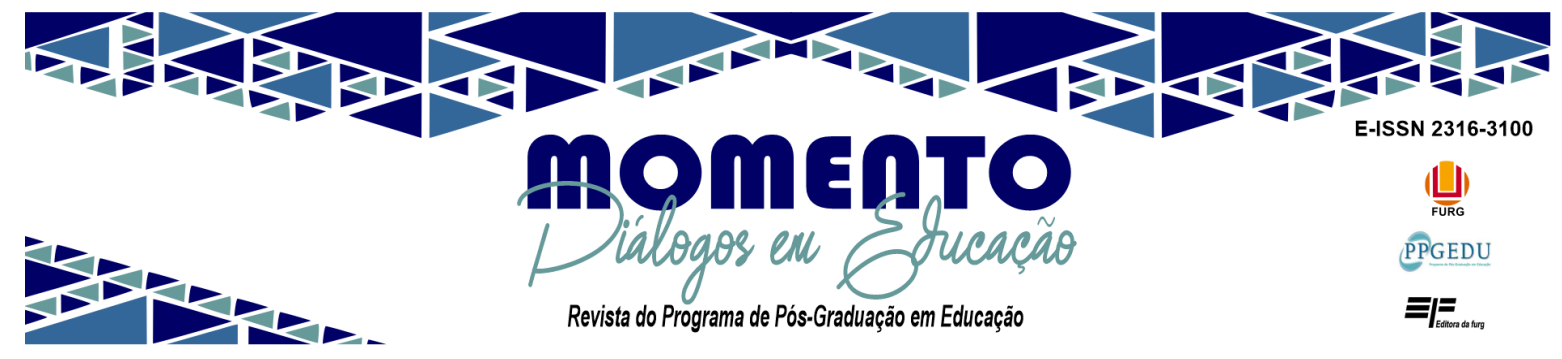

(...)"; para isso, "o professor pode criar uma situação com uma pergunta ou colocar um problema; depois disso, seu papel de professor termina" (idem, p. 286).

Tais concepções ecoam o que Saccomani (2016) já apontara acerca do ideário hegemônico que permeia a visão sobre a criatividade na educação; para a autora, na maioria das teorias educacionais, "o ato de criação está sempre relacionado com um momento livre e autônomo. E o professor, caso intervenha direta e intencionalmente nesse momento, estará cerceando e prejudicando a liberdade e a criatividade do aluno" (SACCOMANI, 2016, p. 33). Trata-se da relação entre ensino e pesquisa já analisada por Saviani (2018, p. 37-39): na medida em que a atividade de ensino foi considerada uma atividade pesquisa a aquisição de conhecimentos deixou de ser o horizonte do processo educativo, sendo substituído pela noção de uma construção individual e espontânea do conhecimento.

Podemos notar, assim, um paralelo com as perspectivas pedagógicas da música: ao passo que nas ideias educacionais em geral a atividade de ensino foi confundida com a atividade de pesquisa, nas ideias acerca da educação musical o ensino foi considerado composição. Se do prisma do ideário pedagógico geral o aluno deve ser entendido como um pesquisador, na aula de música ele deve ser um compositor. Mas, tal qual na relação entre ensino e pesquisa, seria correto comparar o momento da aula com a criação imediata de uma obra de arte, ou seja, como um acontecimento artístico? Ao igualar-se o ensino à composição musical não se estaria também dissolvendo a diferença entre os dois e, portanto, empobrecendo o ensino da música e inviabilizando a composição?

Sem dúvida a dimensão vivencial é um momento importante da aula de música; o problema está em contrapor o desenvolvimento da experiência estética ao domínio dos conteúdos técnicos e teóricos da música. Isso se torna ainda mais problemático se observamos que o esforço histórico para refletir a vida interior humana em um material não imediatamente palpável, como é o som, fez com que as leis da organização estética sejam mais rigorosas na música do que em outras artes e, consequentemente, mais determinantes para o enriquecimento da formação musical. Para Lukács:

Se existe uma arte em que tais regras devem ser levadas a sério, reconhecidas, realmente aprendidas, essa arte é música; é certo que não somente ela, mas ela em primeiro lugar. Precisamente as biografias dos inovadores mais importantes mostram que eles sempre tiveram que passar 


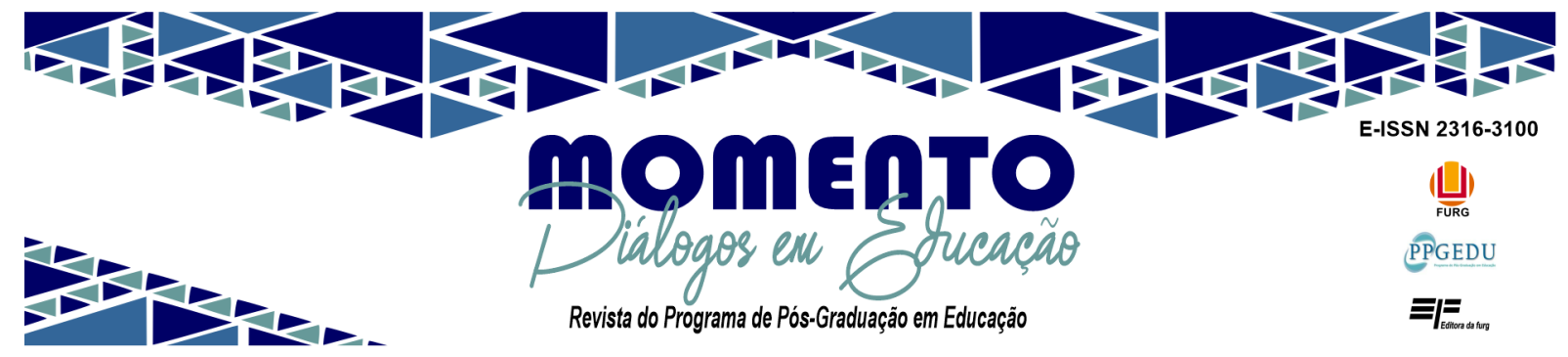

por esse aprendizado para formular o novo de um modo artisticamente adequado, não com um diletantismo; porque, em geral, a fronteira entre o nível artístico e o diletantismo é traçada na música de uma forma muito mais rigorosa e racionalmente justificável do que nas outras artes. Por outro lado, o que foi dito antes sobre a física também se aplica aqui: a observância exata das "regras" da teoria da composição, mesmo que não dê em pedantismo, em escolástica, mas seja correta e até inteligente, original etc. do ponto de vista do teórico especialista, não dá qualquer garantia de que uma obra substantiva de arte musical será produzida. A teoria musical não oferece nada além de possibilidades, leis condicionais negativas, por assim dizer. (LUKÁCS, 1967, p. 16).

Torna-se compreensível, assim, toda a artificialidade da contraposição entre razão e emoção presente nas ideias hegemônicas do ensino da arte, em especial, da música, bem como o esvaziamento curricular que tais perspectivas podem acarretar. Por outro lado, nossas considerações também apontam para um horizonte pedagógico: considerando essa unidade entre a organização racional do conteúdo e a qualidade afetiva desse conteúdo, vêse que uma aula de música não pode se limitar a experiências estéticas isoladas, devendo se orientar pela apropriação dos conteúdos e leis próprias da linguagem artística em questão o que, novamente, não significa diminuir o valor da experiência estética em sala de aula.

Por isso, por paradoxal que possa parecer, uma aula de improvisação pode ser um momento onde se fique mecanicamente estudando escalas no instrumento e uma aula de composição pode ser a execução de exercícios de contraponto. O ensino dos elementos técnicos de cada instrumento, da escrita e da leitura da música, do solfejo e das noções de harmonia, todos estes conteúdos que exigem necessariamente um grau de mecanicidade no seu processo de apreensão, não são válidos por si mesmos, mas somente na medida em que fornecem os subsídios para uma formação musical plena. Como Lukács aponta acima, esses conteúdos não irão garantir, por si só, o enriquecimento da formação musical, sendo somente "possibilidades, leis condicionais negativas"; entretanto, é certo também que a elevação da experiência estética e da criatividade musical não pode ocorrer sem eles.

Esse horizonte pedagógico que emana de uma concepção dialética da unidade afetivo-cognitiva nos processos educacionais - sejam eles da música, das outras artes, ou da ciência - alinha-se ao pressuposto, defendido pela pedagogia histórico-crítica, de que a escola e o trabalho educativo produzam a humanidade em cada indivíduo (SAVIANI, 2012). 


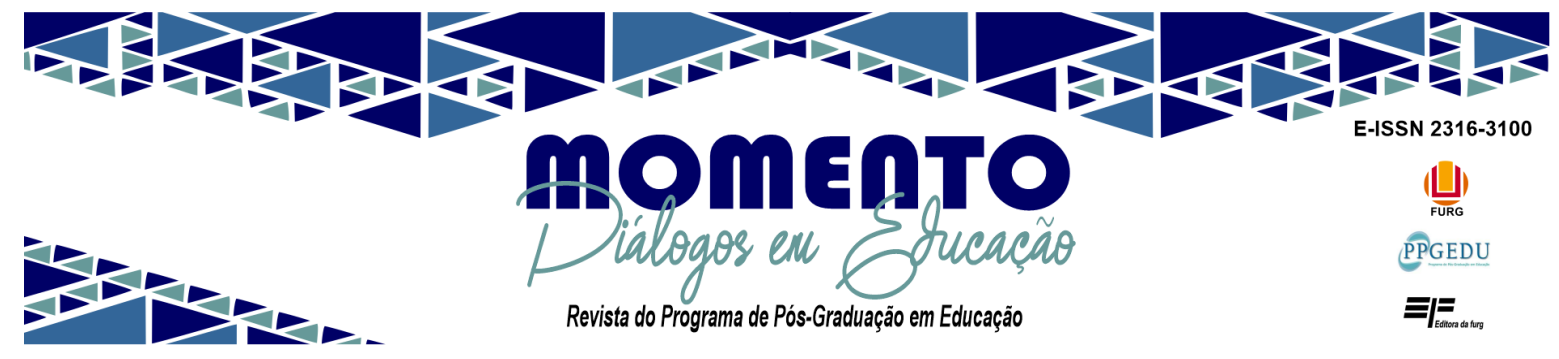

Ou seja, para que cada indivíduo ultrapasse a heterogeneidade de sua vida particular e desenvolva uma relação consciente com o gênero humano, é necessário que ele se aproprie das objetivações mais evoluídas, como a arte, a ciência e a filosofia, cabendo à educação escolar o papel de promover essa apropriação, proporcionando o aprendizado dos conteúdos próprios de cada disciplina.

A experiência afetivo-cognitiva que sustenta semelhante relação entre o indivíduo e as objetivações mais ricas produzidas pelo gênero humano se diferencia qualitativamente daquelas presentes na vida cotidiana no capitalismo, onde a contradição entre o gênero humano e o indivíduo, já destacada acima - isto é, entre o estágio do desenvolvimento coletivo e os limites da vida individual -, promove uma vivência cindida, heterogênea da realidade. A apropriação dessa riqueza genérica proporciona uma experiência homogênea da vida. Na homogeneização o indivíduo converte-se, momentaneamente, segundo Heller, apoiada na estética de Lukács, em "homem inteiramente comprometido":

O "homem inteiramente comprometido" é uma individualidade que concentra todas as suas forças e capacidades no cumprimento de uma única tarefa incorporada na esfera homogênea. A ação humana que surge no processo de homogeneização é sempre atividade (não só psicológica, mas também cognitiva e moral), isto é, um produzir e reproduzir. (HELLER, 1977, p. 116-117, grifo do autor).

Outra característica elementar do processo de homogeneização é a de que a relação com os conteúdos de ensino, ou seja, com as objetivações mais elaboradas exige que o sujeito empregue de forma mais complexa a sua individualidade no sentido de ir além de suas características particulares, ampliando a possibilidade de se compreender os fenômenos da realidade que são bloqueadas no âmbito do cotidiano. É por entendermos as implicações positivas da ciência, da arte, e da filosofia para o desenvolvimento dos indivíduos e da sociedade que nos posicionamos a favor do ensino. É por isso e é nesta direção que afirmamos também que os conteúdos escolares devem se diferenciar daquilo que já está posto no cotidiano de cada aluno.

No que se refere, mais especificamente, à arte entendemos que por meio do contato com as várias modalidades artísticas o aluno pode ver o mundo de maneira mais rica e, mais que isso, pode enriquecer de sentido a sua própria vida, deixando-a mais plena de vivências 


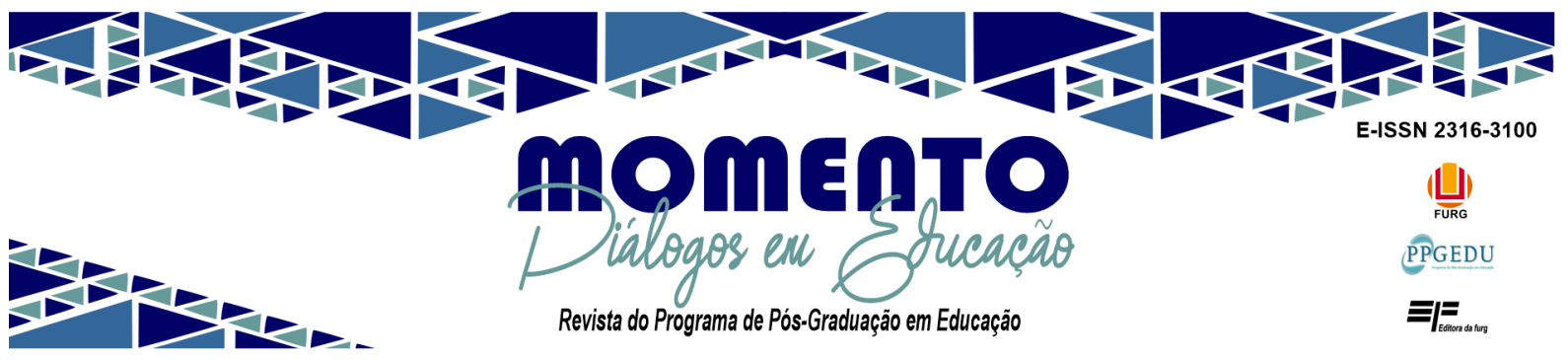

e experiências que o faça alterar, qualitativamente, a sua concepção de mundo, rompendo com as barreiras alienantes e direcionando-se a patamares de desenvolvimento omnilateral (KOSIK, 1976).

O objetivo que devemos alcançar ao ensinarmos as artes para as crianças, desde a educação infantil, passando pelas etapas do ensino fundamental e médio, é fazer com que elas possam analisar a realidade de forma menos fetichizada, consigam, aos poucos, desenvolver a sua sensibilidade e racionalidade de forma mais elaborada, agindo e sentindo o mundo.

A educação comprometida com o pleno desenvolvimento da individualidade é uma educação preocupada em socializar a produção cultual humana universal, criando em cada indivíduo a necessidade de apropriações cada vez mais elaboradas e não uma educação voltada a desenvolver nos indivíduos capacidades de mera adaptação ao status quo. Por isso, a pedagogia histórico-crítica defende a transmissão e apropriação pela classe trabalhadora do conhecimento produzido pela humanidade em suas melhores expressões nos campos da ciência, da arte e da filosofia.

\section{Considerações finais}

Tentando superar uma concepção dicotômica e lógico formal da relação entre emoções, sentimentos e razão, analisamos no presente artigo a unidade afetivo-cognitiva demostrando que ela se apresenta nas diferentes esferas de objetivação humana, como a arte e a ciência e, além disso, é um elemento importante a ser considerado no processo formativo de cada indivíduo.

Para tanto, buscamos a gênese e o desenvolvimento histórico da unidade afetivocognitiva na arte e na ciência, evidenciando que ambas advêm da atividade de trabalho, categoria fundante do ser social. Apontamos, ainda, que tais objetivações humanas são formas específicas de reflexo do real, ou seja, elas se diferenciam na maneira de refletir a realidade, uma vez que a arte é antropomórfica e a ciência é desantropomórfica.

Ao discorrermos sobre as semelhanças e as diferenças entre a arte e ciência ao longo do percurso da história humana, não poderíamos deixar de abordar a questão dos processos 


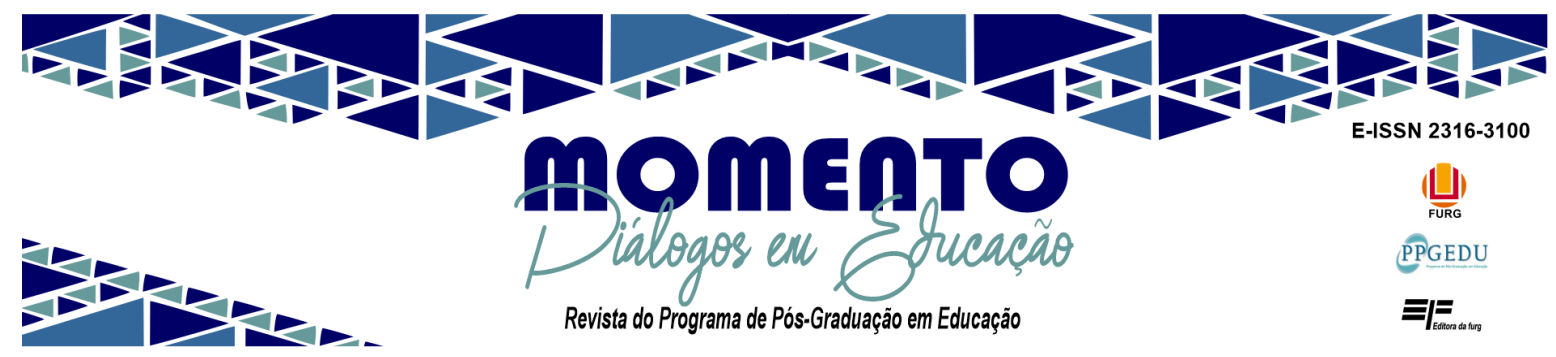

alienantes e da divisão social do trabalho, os quais bloqueiam as possibilidades de formação omnilateral e contribuem para a propagação de ideias equivocadas sobre o papel educativo da arte e da ciência, resultando em currículos esvaziados de conteúdo, que ora tendem ao pragmatismo e ao tecnicismo quando tratam dos aspectos científicos, ora tendem à supervalorização da experiência estética nas várias modalidades artísticas.

Nesse sentido, mostramos a partir do exemplo da música como os aspectos cognitivos e emocionais proporcionam uma relação constante entre o indivíduo e o gênero humano, formando, de fato, uma unidade afetivo-cognitiva que se eleva ao cotidiano alienado e amplia os horizontes da formação humana.

\section{Referências}

DUARTE, Newton. A Individualidade Para-Si: contribuição a uma teoria histórico-social da formação do indivíduo. $3^{\mathrm{a}}$ ed. rev. Campinas: Autores Associados, 2013.

DUARTE, Newton. Os conteúdos escolares e a ressureição dos mortos: contribuição à teoria histórico-crítica do currículo. Campinas, SP: Autores Associados, 2016.

ENGELS, Friedrich. O papel do trabalho na evolução do homem. Brasília: Kiron, 2012. FISCHER, Ernst. A necessidade da arte. São Paulo: Círculo do Livro, 1959.

FONTERRADA, Marisa T. de Oliveira. De tramas e fios: um ensaio sobre música e educação. São Paulo: Editora UNESP, 2008.

GOMES, Cláudia Aparecida Valderramas. A relação sujeito-objeto e a unidade afetivocognitiva: contribuições para a Psicologia e para a Educação. Revista Quadrimestral da Associação Brasileira de Psicologia Escolar e Educacional, SP. v. 18, n. 1, jan/abril 2014: 161-168.

HELLER, Agnes. Sociología de la vida cotidiana. Barcelona: Península, 1977.

JAEGER, Werner W. Paideia: a formação do homem grego. 6. ed. São Paulo: WMF Martins Fontes, 2013.

KIRALYFALVI, Bela. Lukács's Views on Artistic Freedom. In: Leonardo, vol.16, n.2. spring, 1983, pp. 124-126.

KOFLER, Leo; ABENDROTH, Wolfgang; HOLZ, Hans Heinz. Conversando com Lukács. Rio de Janeiro: Paz e Terra, 1969. 


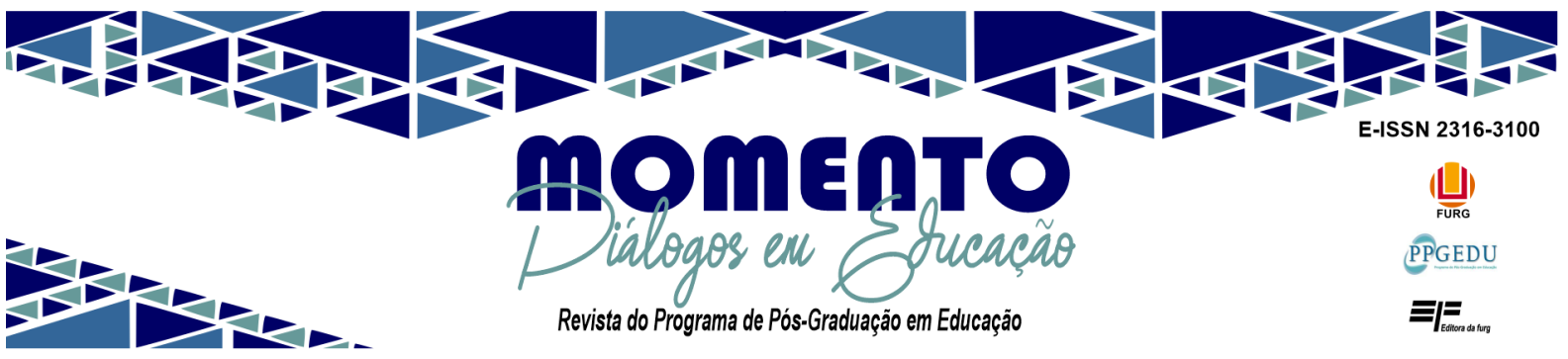

KOSIK, Karel. Dialética do concreto. 2. ed. Rio de Janeiro: Paz e Terra, 1976.

LEITE, Hilusca Alves; SILVA, Renata da; TULESKI, Silvana Calvo. A emoção como função superior. Interfaces da Educação, Paranaíba, v.3, n.7, p.37-48, 2013.

LUKÁCS, Georg. Estetica I: La peculiaridad de lo estetico. v. 1. Cuestiones previas y de princípio. Barcelona: Grijalbo, 1966.

LUKÁCS, Georg. Estetica I: La peculiaridad de lo estetico. v. 4. Categorías básicas de lo estético. Barcelona: Grijalbo, 1967.

LUKÁCS, György. Introdução a uma estética marxista. 2.ed. Rio de Janeiro: Civilização Brasileira, 1968.

LUKÁCS, György. O jovem Marx e outros escritos de filosofia. 2. ed. Rio de Janeiro: Editora UFRJ, 2009.

MACHADO, Letícia Vier; FACCI, Marilda Gonçalves Dias; BARROCO, Sonia Mari Shima. Teoria das emoções em Vigotski. Psicologia em Estudo, Maringá, v. 16, n. 4, p. 647-657, out./dez. 2011.

MÁRKUS, György. Marxismo e antropologia: o conceito de "essência humana" na filosofia de Marx. São Paulo: Expressão Popular, 2015.

MARTINS, Lígia Márcia. A natureza histórico-social da personalidade. Cadernos Cedes, Campinas, v. 24, n. 62, p. 82-99, abril, 2004.

MARTINS, Lígia Márcia. O desenvolvimento do psiquismo e a educação escolar: contribuições à luz da psicologia histórico-cultural e da pedagogia histórico-crítica. Campinas, SP: Autores Associados, 2013.

MARTINS, Lígia Márcia; CARVALHO, Bruna. A atividade humana como unidade afetivocognitiva: um enfoque histórico-cultural. Psicologia em Estudo, Maringá, v. 21, n. 4, p. 699-710, out./dez. 2016.

MARX, Karl. Manuscritos econômico-filosóficos. São Paulo: Boitempo, 2010.

MARX, Karl. O Capital: crítica da economia política: Livro I: o processo de produção do capital. Tradução: Reginaldo Sant'Anna. Rio de Janeiro: Civilização Brasileira, 2013.

MARX, Karl; ENGELS, Friedrich. A ideologia alemã. São Paulo: Boitempo, 2007.

MONTEIRO, Patricia Verlingue Ramires; ROSSLER, João Henrique. A unidade afetivocognitiva: aspectos conceituais e metodológicos a partir da psicologia histórico-cultural. Psicologia Revista, São Paulo, volume 29, n. 2, 310-334, 2020. 


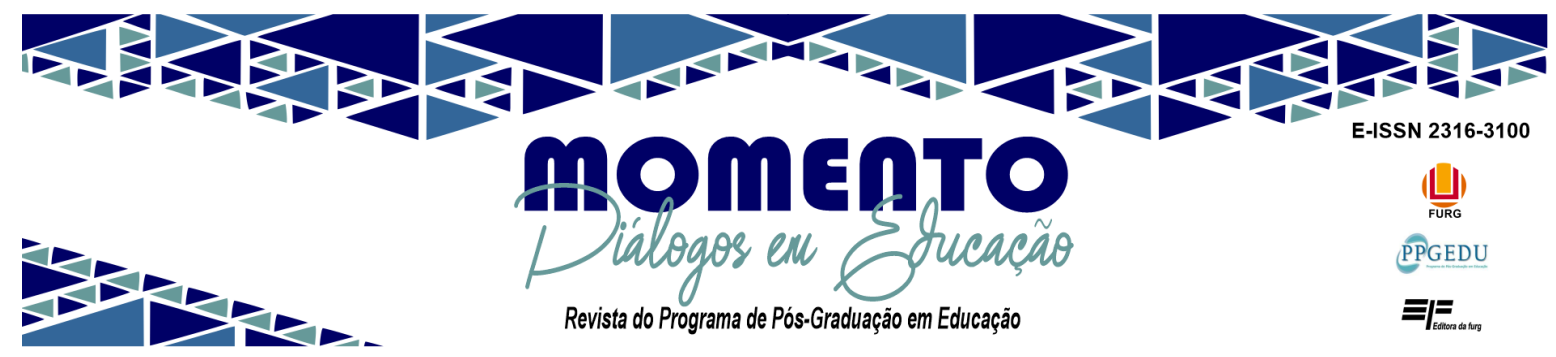

PAUlO NETTO, José; BRAZ, Marcelo. Economia Política: uma introdução crítica. São Paulo: Cortez, 2012.

PAYNTER, John. Making progress with composing. British Journal of Music Education. V. 17, Issue 01, 5 - 31, mar. 2000.

PAYNTER, John. Music in the school curriculum: why bother?. British Journal of Music Education. V. 19, Issue 03, 215 - 226, nov. 2002.

SACCOMANI, Maria Cláudia da Silva. A criatividade na arte e na educação escolar: uma contribuição à pedagogia histórico-crítica à luz de Georg Lukács e Lev Vigotski. Campinas: Autores Associados, 2016.

SAVIANI, Dermeval. Pedagogia histórico-crítica: primeiras aproximações. 11. ed. rev. 1. reimpr. Campinas: Autores Associados, 2012.

SAVIANI, Dermeval. Escola e Democracia. 43 ed. ver. Campinas: Autores Associados, 2018.

SCHAFER, R. Murray. O ouvido pensante. São Paulo: Editora UNESP, 1991.

TEIXEIRA, Anísio. A pedagogia de Dewey. In: WESTBROOK, Robert B.; TEIXEIRA, Anísio; ROMÃO, José Eustáquio; RODRIGUES, Verone Lane (org.). John Dewey. Recife: Fundação Joaquim Nabuco, Editora Massangana, 2010. (Coleção Educadores).

Submissão em: 07-06-2021

Aceito em: 20-07-2021 